\title{
Supply Chain Management and its Route to Normal Science: a Kuhnian Analysis
}

\author{
Rogers Ascef \\ rascef@nps.edu \\ Naval Postgraduate School \\ Geraldo Ferrer \\ gferrer@nps.edu \\ Naval Postgraduate School \\ Steve Mullins \\ sjmullin@nps.edu \\ Naval Postgraduate School
}

ABSTRACT: The evolution of science has intrigued countless scientists. Many philosophers hold that scientific evolution is linear and constantly adding to the overall body of knowledge. Thomas Kuhn changed this view. In his famous work, The Structure of Scientific Revolutions, he proposes a route to normal science. He explains that paradigm shifts are arduous and require long time periods to occur. Using qualitative research combined with a Kuhnian model, we explain the evolution of Supply Chain Management (SCM) from its origins. Some authors have traced SCM evolution with a focus on chronological and linear order. This paper brings a new approach using Kuhnian elements to explain how SCM has matured to its present form. This broad picture manifests the strenuous path of SCM's evolution and helps to explain how it is close to becoming a normal science.

Keys Words: Supply Chain Management, Kuhnian analysis, Supply Chain Management history, Supply Chain Management Science 


\section{INTRODUCTION}

What is supply chain management science? Is it indeed a science? How has it come to be so? What path has it followed? To understand the perspective of supply chain management as a science, one must first trace its progress to what is more popularly known as supply chain management. The phrase supply chain management was first used in 1982 (Blanchard, 2010, p. 58). Thirty years later, one can trace the evolution of a great conceptual transformation concerning the relations and the flow of information, goods, and payments between suppliers, producers, and consumers. SCM has arisen quickly, during which time many existing professional societies and journals have made it their focus, while new societies and journals dedicated to SCM have been created. New disciplines have been introduced in schools, and SCM is now taught at all levels. How, in less than three decades, could such a new concept coalesce so quickly? This article applies a Kuhnian analysis to understand SCM and its evolution.

Thomas Kuhn was one of the most influential philosophers of the 20th century (Godfrey-Smith, 2003). A physicist and a historian, he wrote The Structure of Scientific Revolutions in 1962, in which he discussed the evolution of science. According to Kuhn (1970), science progresses in a long and arduous manner, in a discontinuous process. A scientific concept passes from a pre-paradigmatic period through revolutionary science, until it becomes mature. Inspired by the history of science, Kuhn's work shows how science travels along that route.

Many researchers have since applied Kuhn's model to explain the evolution of their particular domain. Cushing (1989) and Wells (1976) used it to explain accounting science. Drakopoulos \& Karayiannis (2005) and Blaug (1975) analyze the evolution of economics and even compare the Kuhnian approach with those of other philosophers such as Lakatos and Popper. Lummus et al (2001) analyzes the evolution of SCM and logistics, and Ballou (2007) examines the evolution of SCM by chronologically analyzing its elements. However, SCM enjoys no prior work that attempts to explain its evolution in a Kuhnian context.

This study seeks to identify the past and ongoing evolution of SCM using a Kuhnian approach to fill that gap. To this end, we apply an historical narrative combined with Kuhn-based models to understand the route of SCM toward normal science. This approach helps in understanding the evolution of
SCM, and why it is becoming a new social science by asking the question: Is Supply Chain Management a new consensus "science"? We examine past developments in order to understand the phenomenon of interest, to interpret it, and to seek its meaning in the context of Supply Chain Management evolution (Denzin \& Lincoln, 2005).

The research combines a qualitative historical account using Kuhn's model to evaluate a knowledge domain to answer the question. Our process follows these steps (Johnson \& Christensen, 2008, pp. 425-434):

- We review the literature about aspects of Kuhn's theoretical work, and present other studies that apply Kuhn to analyze scientific evolution.

- We collect data on facts about logistics and the supply chain knowledge domain that have occurred over time.

- We assign the data to each step of the model of the route to normal science.

- We analyze the data and indicate in which state SCM stands in its progression toward becoming a normal science, based on Kuhn's work.

The remainder of this article is structured in three sections. In the following section, we review the process as outlined by Kuhn. The main ideas and concepts are presented with a criticism of the application of Kuhnian analysis in the Social Sciences. Later, we propose a model of the route that SCM has traveled toward normal science, showing the transition from the pre-paradigmatic period to revolutionary science and to normal science. Finally, we offer conclusions and show where SCM stands today in this context.

\section{ELEMENTS OF KUHN'S THEORY}

By the time Kuhn wrote The Structure of Scientific Revolutions in 1962, the scientific community had witnessed fantastic discoveries in the physical and other sciences. Logical positivism was the predominant perspective in the natural sciences, logic and mathematics. The logical positivists claimed that science must be used for experimentation to compare theories with facts. They worried less about how one arrives at a hypothesis; if the hypothesis test was a success, the theory was valid. They were ahistorical about the process of theory development (Okasha, 2002). 
Kuhn started his career earning a doctorate in physics in 1949. He then became involved in an experimental college course that provided his first contact with the history of science, to which he shifted his focus. Later, he began to teach the history of science and develop his theories, until publishing his book (Bird, 2012). It shattered traditional myths about science, especially empiricist myths (Godfrey-Smith, 2003, p. 75). The Guardian Newspaper suggested that Structure is one of the 100 most influential books of the 20th century (Okasha, p.77).

\subsection{Basic Definitions}

"History suggests that the road to a firm research consensus is extraordinarily arduous". When this consensus occurs, however, "normal science" has been established. In this context, normal science is defined as "research firmly based upon one or more past scientific achievements, achievements that some particular scientific community acknowledges for a time as supplying the foundation for its further practice" (Kuhn, 1970). Normal science primarily involves matters of puzzle solving (Okasha, 2002), but for Kuhn, a puzzle is different from a problem; a puzzle has not been solved yet-but it does have a solution. A problem might not have a solution (Godfrey-Smith, 2003, p. 81).

Kuhn (1970) argues that science develops through the addition of a new thrust to the stock of an old thrust. A mature science undergoes alternating normal and revolutionary phases. Normal science has key theories and values that help to solve many puzzles and a disciplinary matrix to accumulate knowledge. Often, a new truth does not fit the old paradigm. When this truth is scarce, it can be ignored; when it increases, a crisis starts in the scientific community, and the disciplinary matrix undergoes revision (Bird, 2012).

It is during the Revolutionary Science phase that an existing paradigm breaks down: "fundamentals and scientific ideas are up for grabs," various alternatives "are proposed to explain the new phenomenon, and eventually, a new paradigm becomes established." At this time begins the competition of a scientific revolution. Not all achievements of the preceding period of normal science are preserved. This completion can take perhaps a generation or more of scientists, and ends when the old paradigm shifts to a new one and the community accepts the new paradigm (Okasha, 2002, pp. 82-83).
Kuhn (1970) explains that paradigms are "the most novel and least understood aspect" in his book. Paradigms don't contain key theories and laws, but rather take these theories and laws to solve important puzzles with new experimental or mathematical techniques (Bird, 2012). Okasha (2002) further explains that a paradigm is an "entire scientific outlook - a constellation of shared assumptions, beliefs and values that unite a scientific community and allow normal science to take place".

\subsection{The Route to Normal Science}

The transformation to normal science is not an easy one; development does not happen quickly. Transformation takes a long time, beginning with many small but interconnected findings (Kuhn, 1970). A succession of many paradigm transformations creates a scientific revolution. A transformation can start a long time before new paradigms are conceived. During these times, scientists contribute what he calls a "paradigmatic observation." Special clusters are formed that explain particular facts of a phenomenon, but they remain as outstanding problems for further research (Kuhn, 1970, p. 12). "Kuhn describes an immature science, in what he sometimes calls its 'pre-paradigm' period, as lacking consensus. Competing schools of thought possess differing procedures, theories, and even metaphysical presuppositions. Consequently there is little opportunity for collective progress" (Bird, 2012).

During a pre-paradigm period, facts and observations begin to arise. When the observations can no longer be reconciled with the old paradigm, these observations transform into anomalies. These are puzzles that have resisted a solution. When anomalies arise, new paradigms may appear to explain the phenomenon. The surge of new paradigms marks the beginning of a period of revolutionary science (Okasha, 2002, p. 82).

A new paradigm brings puzzle solutions that may not solve all problems, but the puzzle solution may suggest other puzzles of the same kind that can offer new opportunities to research using the same approach that the puzzle solution used. This time, after competition between paradigms subsides, a paradigm consensus develops as a group or an individual produces syntheses that attract more students of that knowledge domain (Kuhn, 1970).

When normal science begins, students of that knowledge domain convert to a new paradigm and new 
schools appear. The research community develops specialized equipment and techniques to investigate specific questions. Rigid definitions are created and the group begins a new discipline and profession. With the rise of knowledge, there are "formations of specialized journals and foundations of specialists' societies" (Kuhn, 1970).

With the definition consolidated, scientists initiate in-depth research and record their findings in books. The normal science is consolidated until new para- digms appear and the cycle starts again. Numerous authors apply Kuhn's path to explain the evolution of their particular sciences. Gary Gutting's bibliography lists 119 works about Thomas Kuhn in a variety of sciences (Cushing, 1989).

Figure 1 represents the route to normal science, illustrating that the path is long. Sometimes, paradigmatic observations don't arise during the period of revolutionary science; knowledge is there, waiting for new observations to start a revolution.

\section{Figure 1. A Model of the Route to Normal Science The Route to Normal Science}

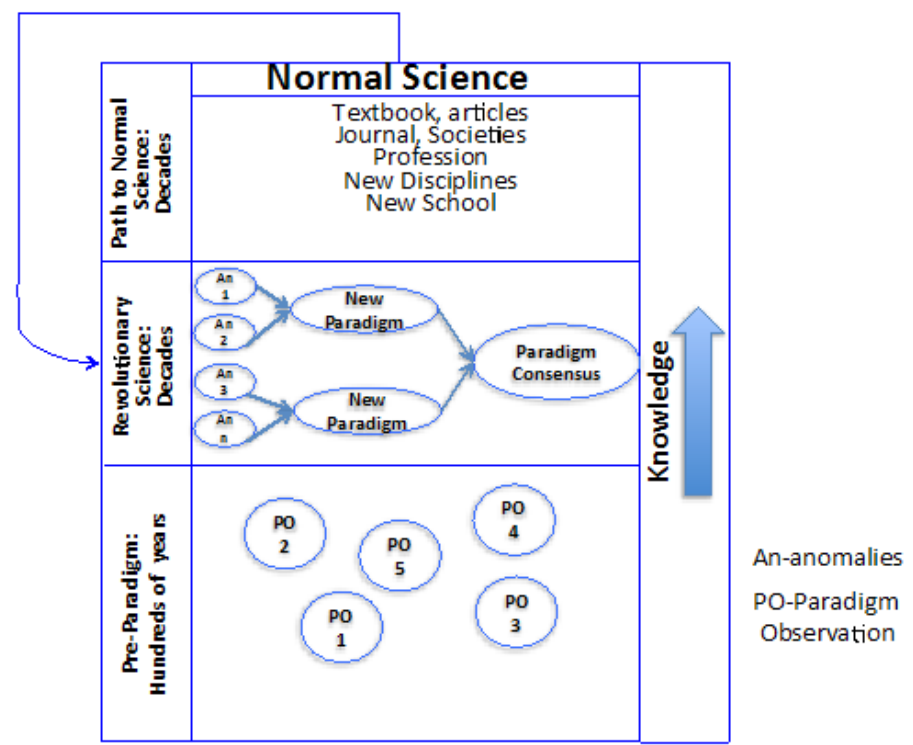

\subsection{Criticisms}

Philosophers continue to debate Kuhn's theory, in particular his description of scientific revolutions and the incommensurability problem. The two terms help to portray the evolution of supply chain management, so we will take a moment to discuss other authors' issues with these concepts.

\subsubsection{Scientific Revolutions}

Kuhn argued that when a knowledge domain is transformed into normal science, the main ground is closed for debate. However, Popper claims the opposite. Popper argues that a "good scientist is open-minded with respect to all issues that they are researching, even the very basic issues" (GodfreySmith, 2003, p. 81).

Stephen Toulmin contends that "revisionary changes in science are far more common and less dramatic than Kuhn supposes. Kuhn argues that revolutionary science occurs because new anomalies arise, but according to Toulmin, revolutionary science can come from normal science too." (Bird, 2012).

Subsequent to Kuhn publishing his book, Imre Lakatos organized a conference to discuss the divergent ideas of Kuhn and Popper. Narasimhan (1997) summarizes their main ideas, shown in Table 1. 
Table 1 A comparison between Kuhn's and Popper's ideas (Narasimhan, 1997)

\begin{tabular}{|l|l|l|}
\hline Disagreement Ideas & \multicolumn{1}{|c|}{ Kuhn } & \multicolumn{1}{|c|}{ Popper } \\
\hline $\begin{array}{l}\text { Existence and role of } \\
\text { normal science }\end{array}$ & $\begin{array}{l}\text { Development of scientific } \\
\text { knowledge is visualized as } \\
\text { comprising a 'normal' and a } \\
\text { revolutionary'phase }\end{array}$ & $\begin{array}{l}\text { Criticism plays a central role in } \\
\text { the growth of knowledge and its } \\
\text { absence in any phase of scientific } \\
\text { growth is unacceptable. Scientific } \\
\text { growth is achieved through prob- } \\
\text { lem solving and moving from one } \\
\text { set of problems to another }\end{array}$ \\
\hline $\begin{array}{l}\text { Role played by socio- } \\
\text { logical and psychologi- } \\
\text { cal factors }\end{array}$ & $\begin{array}{l}\text { They play an important role } \\
\text { in the growth of scientific } \\
\text { knowledge, generally medi- } \\
\text { ated through the scientific } \\
\text { community }\end{array}$ & $\begin{array}{l}\text { Sociology and psychology are } \\
\text { spurious sciences. Only logic of } \\
\text { discovery can lead to enlighten- } \\
\text { ment concerning the aims of sci- } \\
\text { ence }\end{array}$ \\
\hline $\begin{array}{l}\text { Manner by which sci- } \\
\text { entific change occurs }\end{array}$ & $\begin{array}{l}\text { Scientific change is not ac- } \\
\text { cessible to any rational or } \\
\text { logical explanation. It is due } \\
\text { to a gestalt switch rather than } \\
\text { a smooth transition from one } \\
\text { paradigm to another }\end{array}$ & $\begin{array}{l}\text { There is the possibility of rational } \\
\text { comparison in science as distinct } \\
\text { from theology. Only in science is } \\
\text { progress possible }\end{array}$ \\
\hline
\end{tabular}

Lakatos claims that all history of science can be similarly described. He defines any attempt to do so as internal history. External history is defined as any failure of scientists to act according to the Methodology of Scientific Research Programs (MSRP). MSRP was intended for constructing and evaluating research programs, an approach unique among philosophers of science. "The 'hard core' of this programme is a framework of general hypotheses. This hard core would not be falsified by followers of that programme." (Drakopoulos \& Karayiannis, 2005).

\subsubsection{Incommensurability}

The incommensurability thesis presents a challenge to positivist and realist concepts. The positivists believe that observations are independent and that different scientists should observe the same phenomenon and interpret it the same way. For realists, the truth depends only on the point of reference and not on the senses. Consequently, "there is no inference to the inadmissibility of the comparison of theories with respect to their truth-nearness" (Bird, 2012).

Okasha (2002) explains that, because of the incommensurability thesis, "two paradigms may be so different as to render impossible any straightfor- ward comparison of them with each other. Not many philosophers were convinced with the incommensurability thesis because they thought that if old and new paradigms were not incompatible," there would be no need to choose between them. In response to this argument, Kuhn modified his statement, that while perhaps not impossible, comparison might be difficult.

\subsection{Applicability of Kuhnian Approach to the Social Sci- ences}

After explaining some key elements of Kuhn's philosophy of science and its criticism, we illustrate an example. Cushing (1989) produced interesting work about the evolution of accounting, employing a Kuhnian interpretation to show its historical path. Cushing argues that Kuhn's framework helps him to "understand better the past and present of the accounting discipline". In his analysis, Kuhn's theory helps to "put the accounting discipline in perspective by creating an awareness that it may have important similarities with other intellectual disciplines". He further shows that the progress of the accounting discipline might be noncumulative. To demonstrate the utility of applying Kuhn to the history of accounting, Cushing showed the job of the philoso- 
pher Gary Gutting, who had assembled an anthology of different papers that examine the discipline's history from the perspective of Structure. Gutting's bibliography lists 119 works about Thomas Kuhn in a variety of sciences. Cushing argues that if a Kuhnian approach can be applied to diverse disciplines, "then surely they must have some relevance to the accounting discipline" (Cushing, 1989, p. 11). Cushing's study defines what an accounting paradigm is and at what stage accounting was at that time.

A study about the evolution of economics by Mark Blaug (1975) describes and compares Kuhn's and Lakatos' theories. He claims that economists are reluctant to accept Kuhn because of "the destructive effect of naïve falsifications on budding research programs". He starts with the Kuhnian methodology wherein he references several studies on economic paradigms and their revolutions. He later demonstrates the applicability of Lakatos, showing that the Methodology of Scientific Research Programs gives "a powerful handle" for showing economic evolutions. He concludes that "a Lakatosian rational reconstruction would suffice to explain virtually all past successes and failures of economic research programmes" (Blaug, 1975).

Yet Drakopoulos \& Karayiannis (2005) argue that Kuhn's theory is vague in its terminology, inappropriate for economics, and that it has problems with empirical testing. They conclude that "ideas imported from the philosophy of the Natural Sciences seem to be inadequate and rather limiting for economic thought. They contend that "other alternative models of scientific evaluation might be more appropriate for the case of economics."

To summarize, numerous papers attempt to explain scientific evolution using Kuhn's or Lakatos' theories. We view that there are strong and weak points in each, but that both theories can help the reader to understand the evolution of science. Accordingly, this paper analyzes the evolution of Supply Chain Management using Kuhn's theory because its steps fit well and appear, in our view, to better explain its evolution.

\section{THE ROUTE OF SCM TO NORMAL SCIENCE}

This section is divided into the pre-paradigm period, the revolutionary science period, and the route to normal science following Kuhn's analysis, as it applies to SCM.

\subsection{Pre-Paradigm Period}

The first paradigm that history reveals is the term "logistics." Although the term had not yet been coined with a real definition, "logistical" concepts were used in many military campaigns with no consolidation of a real concept. Those military campaigns employed notions of logistics that invariably involved the movement of physical goods from one location to another. The route to revolutionary science begins with paradigmatic observations and is characterized by several incompatible and incomplete concepts and theories.

The first reported use of the term "logistics" is seen during the time of Alexander the Great (356-323 BC). He focused on sufficient logistical support for his army to conquer the many territories that he attacked. Alexander used logistics to undergird his strategy and tactics. The paramount problems for his army were supply, transportation and mobility. Due to distance and the deficiencies of long-range communications of the day, sufficient supplies were vital to the success of his campaigns. Alexander ensured that his army was "the fastest, lightest and most mobile force in existence" (Engels, 1980). He succeeded by creating a new type of army, in which he trained his soldiers to carry their full panoply. Servants and not animals transported many materials. His troops and a restricted number of servants and animals carried nearly all supplies. This decreased the required quantity of food and supplies to be transported. Supply was the basis of Alexander's strategy; he dramatically reduced his troops' baggage, increasing mobility and speed. With this structure and the best logistics of his time, his armies' range was greatly extended. (Engels, 1980)

The Roman Empire (264 BC - 235 AD) adopted some of Alexander's logistical tactics, but further developed their own. The advent of the term "logistics" can be traced to the ancient wartime of the Roman Empire when military officers known as "logistikas" were responsible to supply and manage the resources of the different Roman legions (Roth, 2012). At that time, the Roman army created an efficient logistical system. They produced detailed records and understood the importance of a strong supply base. Roth (2012) writes that one of major reasons for the Romans' military success was a "careful and highly organized supply system." Their army did not depend primarily on foraging for its provisions because it was supplied from a sophisticated and carefully thought-out system. 
Fundamentally, their system used an operational base 50 miles behind the lines, where supplies were collected and transported forward to the maneuvering army. A tactical base was kept in the army's immediate vicinity. The operational base was always linked to a strategic base by the sea. The Romans developed an efficient maritime transportation chain to support all operational bases. In addition, as is well known, the Romans created a large road network to facilitate transportation (Eckstein, 2000). Their supply system can be related to systems of logistics management to this day.

Another example of logistics used in the past was Genghis Khan's campaign (1162-1227). Specialized troops of craftsmen were skilled in building complex siege machines from local materials eliminating the need to transport them over long distances to the siege location. They perfected the sapping of walls, rendering static defenses impossible (Weatherford, 2004).

The Napoleonic Age generated a concept of logistics that the French "defined as the art of moving troops." This French term "logistique" is found in The Oxford Dictionary published in 1898. An entry written by William Lewer defined logistics as "the art of moving and quartering troops, i.e., quartermaster-general's work" (Lummus, Krumwiede, \& Vokurka, 2001; Oxford, 2012). The Dictionary of Modern War describes logistics as "all activities and methods connected with the supply of armed force organizations, including storage requirements, transport and distribution" (Luttwak, 1971).

From 330 BC to 1900 AD, the evolution of the concept progressed quite slowly. Kuhn discusses this same phenomenon, referring to electricity theory when he writes that the "first four decades of the 18th century possessed far more information about electrical phenomena than had their 16th century predecessors" (Kuhn, 1970). Perhaps we can say that the 20th century was the age of supply chain evolution.

During World Wars I and II, logistics was critical to support great movements of troops and supplies. Military schools intensified the use of the term, and it came to represent manifold functions including procurement, maintenance, and transportation of military facilities, materiel, and personnel (Ballou, 2007).

\subsection{Revolutionary Science Period}

In the 20th century, the term logistics finally was defined, but many anomalies arose related to the term.
The term logistics could not explain all of the concepts and theories that were developed. Logistics as a concept remained very fragmented. Ballou (2007, p. 333) says that a reason for this was a lack of understanding of key cost tradeoffs, the inertia of traditions and conventions, and the evolutionary state of organizations at the time. From the 1950s to the 1970s, companies did not seem to realize that each functional activity depended on the others. That was when two principal activities developed separately: materials management and physical distribution.

Subsequently, many theories and techniques seemed to integrate other functional terms that are used by industry, such as material requirement planning -1964 (Ptak \& Smith, 2011), reverse logistics -1971 (Ferrer \& Whybark, 2001; Zikmund \& Stanton, 1971), customer/supplier relationship - 1969 (Shaw, 1969), theory of constraint -1984 (Goldratt \& Cox, 2004), and lean manufacturing -1988 (Krafcik, 1988), confirming Kuhn's observation that "prior to the 'revolution' there were many small areas of research founded on different assumptions or attempting to explain different phenomena" (Kuhn, 1970).

By the end of the 1970s, many terms were in use, such as distribution, logistics, material management, and value chains, but they were not integrated. Production and purchasing were studied separately (Ballou, 2007). The anomalies accumulated to the point where it became difficult for logistics to cover all new concepts. Kuhn refers to this as a crisis. The community needed to consolidate its body of knowledge. In 1985, the National Council of Physical Distribution Management was renamed the Council of Logistics Management (CLM), offering this definition:

Logistics Management plans, implements, and controls the efficient, effective forward and reverse flow and storage of goods, services and related information between the point of origin and the point of consumption in order to meet customers' requirements (CLM, 1998, cited by Lummus et al., 2001, p. 426).

This definition sought to integrate the domains of materiel management and physical distribution. Its key attributes are integrated management, process orientation, and a focus on customer requirements.

Despite the advent of a logistics management definition, this term did not embrace all concepts. Logistics is so connected with transportation and distribution that it was difficult to incorporate the relationship among 
suppliers, producers, and customers, in addition to material management. In 1982, British logistician and consultant Keith Oliver "began to develop a vision for tearing down the functional silos that separated production, marketing, distribution, sales, and finance to generate a step-function reduction in inventory and a simultaneous improvement in customer service. Looking for a catchy phrase to describe the concept, the consulting team proposed the term 'integrated inventory management"' (Laseter \& Oliver, 2003).

In a public interview with the Financial Times on June 4,1982 , he was the first to use the term "supply chain management" (Blanchard, 2010). Since Oliver's first use of the term, an intense debate arose between "logistics" and "supply chain" and the definition was revised many times. It caused Ballou (2007) to ask exactly what SCM was, when compared with logistics and physical distribution.

In 2004, the Council of Logistics Management was renamed again to the Council of Supply Chain Management Professionals (CSCMP). The CSCMP redefined supply chain management as encompassing:

...the planning and management of all activities involved in sourcing and procurement, conversion, and all Logistics Management activities. Importantly, it also includes coordination and collaboration with channel partners, which can be suppliers, intermediaries, third-party service providers, and customers. In essence, Supply Chain Management integrates supply and demand management within and across companies. (CSCMP, 2004)

Figure 2. The evolution of supply chain management. (After Ballou, 2007, p. 338).

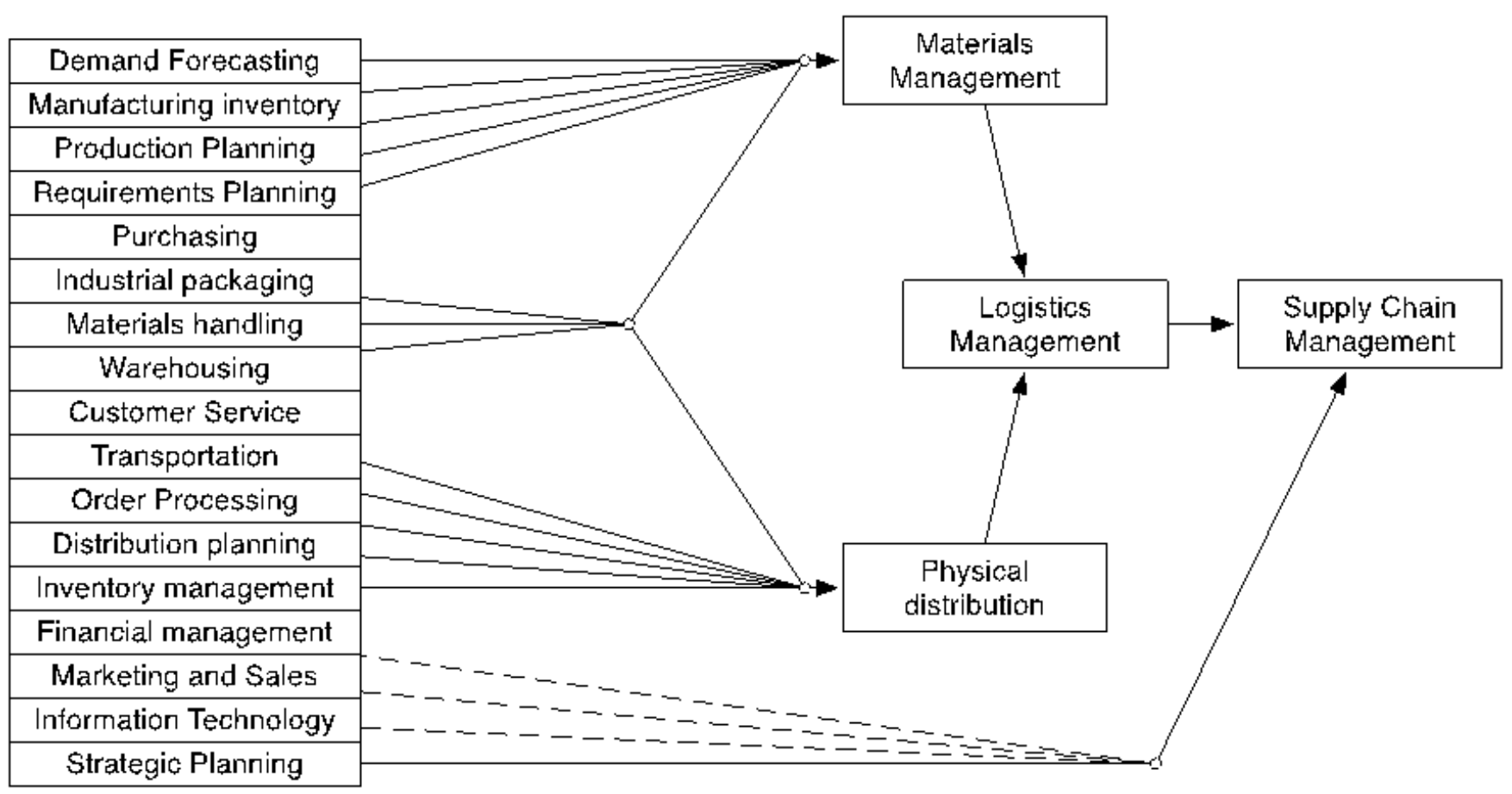

This new definition integrated products, information, and cash flow management throughout all channels. In Figure 1. , Ballou (2007) illustrates this evolution. One can see that supply chain management integrates the management of product flow processes across functions and between channel members. Secondly, logistics is regarded as a subset of SCM. Finally, purchasing and production are within the scope of SCM. Many areas of a firm embrace SCM (Ballou, 2007). "Collaboration among supply chain members is at the heart of SCM and will be the key to its future success" (Ballou, 2007, p. 344). A new paradigm arises and revolutionary science happens. At that point, SCM is on its way to becoming normal science again. 


\subsection{Consolidation to Normal Science}

Kuhn (1970) affirms that the consolidation of a new paradigm can require as much as 1 or 2 generations of scientists. He suggests that revolutionary science would be sufficiently open-ended to enable others to develop theories from new paradigms. The debates about logistics and supply chains still continue, but now the concepts of SCM have been consolidated. "Indeed, by today's standards, the original scope of supply chain management appears quite narrow" (Laseter \& Oliver, 2003). But the path to normal science wasn't easy, because the term SCM is quite new. Kuhn suggests that the path to normal science passes through rigid definition, the creation of a discipline, a journal and a textbook. We examine these points.

\subsubsection{Definition and Key Ideas}

The first step to normal science is the definition. Kuhn writes that a group produces a synthesis and, with this definition, other members converge to a new paradigm. At that time, the new group would establish a rigid definition (Kuhn, p. 19). Philosophers have tried to prove a distinction between scientific knowledge and its look-alikes. This distinction, called the demarcation problem, is "part of the larger task to determine which beliefs are epistemically warranted" (Hansson, 2012). Although we have an approved definition of SCM by the CSCMP, many authors still define SCM differently. Table 2 shows some of these definitions:

\section{Table 2 - Various recent definitions of SCM}

\begin{tabular}{|l|l|}
\hline \multicolumn{1}{|c|}{ Definition of SCM } & \multicolumn{1}{|c|}{ Reference } \\
\hline $\begin{array}{l}\text { A set of approaches used to efficiently integrate suppliers, manu- } \\
\text { facturers, warehouses, and stores, so that merchandise is produced } \\
\text { and distributed in the right quantities, to the right locations, and at } \\
\text { the right time, in order to minimize system-wide cost while satisfy- } \\
\text { ing level requirements. }\end{array}$ & $\begin{array}{l}\text { (Simchi-Levi, Kaminsky, } \\
\text { \& Simchi-Levi, 2007) }\end{array}$ \\
\hline $\begin{array}{l}\text { The integration of the activities that procure materials and services, } \\
\text { transform them into intermediate goods and final products, and } \\
\text { deliver them to customers. }\end{array}$ & (Heizer \& Render, 2007) \\
\hline $\begin{array}{l}\text { SCM consists of all stages involved, directly or indirectly, in ful- } \\
\text { filling a customer request. }\end{array}$ & (Meindl \& Chopra, 2003) \\
\hline $\begin{array}{l}\text { The integration of key business processes from end-users through } \\
\text { original suppliers that provide products, services, and information } \\
\text { that add value for customers and other stakeholders. }\end{array}$ & (Lambert, 2008) \\
\hline $\begin{array}{l}\text { The management of materials and information across the entire } \\
\text { supply chain, from suppliers to component producers to final as- } \\
\text { semblers to distribution (warehouse and retailers), and ultimately } \\
\text { to the consumer. }\end{array}$ & (Silver, Pyke, \& Peterson, \\
\hline & 1998) \\
\hline
\end{tabular}

A review of these definitions demonstrates that SCM integrates the supplier-producer-distributercustomer cycle. In reality, the definitions are so broad because SCM addresses nearly all corporate functions. SCM studies how a supplier can influence a company and a customer, and how a company interacts with its suppliers and customers. So, SCM appears to study all interactions - inside a company, among suppliers, and with customers.

\subsubsection{SCM Theories}

In the supply chain environment a question still remains: what is the theory of supply chain management? Halldorsson et al. explain that "depending on the concrete situation, one can choose one theory as the dominant explanatory theory, and then complement it with one or several of the other theoretical perspectives" (Halldorsson, Kotzab, Mikkola, \& 
Skjøtt-Larsen, 2007). Ketchen \& Hult write that organization theory has the potential to offer provocative and helpful wisdom to the field of SCM. As a result, enormous opportunities exist to integrate insights from organization theory to understand why some supply chains excel while others do not (Ketchen \& Hult, 2007).

In his 2011 book, Hopp (2011, pp. 6-7) presented an interesting definition of Supply Chain (SC):

"....a goal-oriented network of processes and stock points used to deliver goods and services to customers. Processes represent the individual activities involved in the maintenance tasks and distribution of goods and services. The stock points represent locations in the supply chain where inventory are held."

Behind Hopp's definition lie two important theories: System Theory and Network Theory (Barabási, 2003; Bertalanffy, 1969; Capra, 1996). Supply Chain Management is at the juncture of many systems that connect though informational and physical networks. If a Supply Chain is a large system and a network, then SCM follows the principles of these theories.

Consider a supply chain comprising many organizations. Each organization comprises its own system because within it, there are many processes receiving inputs and generating output. An organization's output is an input to another organization or to customers. Once again, all elements are connected. This connection with all elements of the Supply Chain can influence others. In some situations, supply chain components can cause instability. However, the system constantly attempts to correct this disequilibrium (Senge, 2006).

Capra (1996, p. 41) states that general system theory "is a general science of wholeness. That everything is connected to everything". Sometimes, disequilibrium occurs when a company dies or when an evolution occurs. This disequilibrium is caused by feedback that each system receives due to its network connection. Following Barabási (2003), all things are connected, directly or indirectly. All elements of the supply chain form a large system and a big network. Consequently, one supply chain interacts with other supply chains, and all companies are connected directly or indirectly. What we study in supply chains are the forms that cause disequilibrium in the system and the solutions to reduce the problems that the imbalance creates.

\subsubsection{A Discipline and a Profession}

Kuhn (1970) says that "a paradigm transforms a group previously interested merely in the study of nature into a profession or, at least, a discipline." SCM has enjoyed great success in this area. It has been almost 30 years since Oliver first uttered the phrase. Courses and classes about supply chain quickly emerged as universities and institutes responded to the increasing demand for this body of knowledge.

This progress however, was not without challenges. A dissertation by Ellis in 2011 analyzes the similarity in degree requirements between the undergraduate SCM programs in a number of schools. She identified 434 courses and 44 unique subject categories, showing little common ground between all the programs (Ellis, 2011, p. 97). Her conclusion is that "excluded from the curriculum data, there was little similarity in degree requirements between the undergraduate SCM programs in the sample population" (Ellis, 2011, p. 120). She concludes that "the curriculum content also allows one to evaluate complaints by those in academia and industry who claim existing SCM curriculum is inadequate in terms of meeting today's business needs" (Ellis, 2011, p. 125). She suggests that "concerted effort is needed to align SCM degree program curricula with the needs of modern business dynamics" (Ellis, 2011, p. 128). Mawhinney, however, states that there is an agreement on the core concepts in SCM curriculum and in the knowledge, skills, and abilities expected by SCM executives hiring graduates from college undergraduate SCM programs (Mawhinney, 2009).

Today many universities have business departments offering SCM certificates and concentrations in BS, MBA and PhD degree programs in management (Ellis, 2011, p. 112). This trend evolved so quickly that it would be easy to forget that SCM is new, and that the discipline exists but it has yet to standardize.

Maloni attempts to list the main universities according to the faculty doing research in SCM (Maloni, Carter, \& Kaufmann, 2012). Any such list would be quite controversial, considering that it would be difficult to define a methodology that accurately represents the long-term relevance of the body of research executed in any one school, let alone hundreds of institutes doing supply chain research worldwide. Nonetheless, it is notable that their research is an extension of a series of studies dating back to 1967 that "evaluates faculty publication productivity in 
refereed supply chain management and logistics journals". In their particular case, the academic institutions were selected based on the publication data in six journals focused on SCM and logistics during the period from 2008 through 2010.

And, as a great number of courses are available, a new profession has begun. Dischinger, Closs, McCulloch, Speier, \& Al (2006) show the skills and capabilities in five main SCM areas. A professional: "1. functional, 2. technical, 3. leadership, 4. global management, and 5. experience and credibility." They write of an experience at IBM creating a formal SCM career. This "career path targeted consistently highperforming employees and managers who seek to learn and apply broad, cross--functional supply chain expertise and want to be recognized as supply chain management professionals".

Rossetti \& Dooley (2010) analyze SCM-related job descriptions via computerized text analysis. They find tentative support that industry views a SCM professional as a process manager. Their results "indicate that SCM is becoming a more analytical field with tight links to information systems".

\subsubsection{Societies, Journals and Textbooks}

Today among the many councils and professional societies, one can find the Council of Supply Chain Management Professionals - CSCMP and the Association for Supply Chain and Operations Management (APICS) that provides certificated, educational, career development, and networking opportunities to members and to the entire Supply Chain Management profession. The many SCM-related entities seek to share knowledge and improve skills. There are a great number of societies.

There are also many journals in which SCM is researched. The ISI Web of Knowledge indexes more than 11,000 science and social science journals to see the impact factor of each journal. Many SCM Journals in 2000 didn't have an ISI factor (Chapman \& Ellinger, 2009). The methodology now covers the main SCM journals. At Appendix A there are examples of journals of logistics, operations management, supply chain management, and transportation. Some researchers assess the credibility of SCM journals. See for example, papers from Maloni et al (2012) and Carter, Easton, Vellenga, \& Allen (2009). They analyze the rankings of schools of SCM and compare the papers from those schools that have been published in logistics, SCM and transportation journals.
Kuhn (1970) stated that the final step witnesses the preparation of textbooks, and occurs when the paradigm "can be taken for granted, the scientist needs to build his field anew, starting from principles and justifying the use of each concept introduced". At this point, a paradigm is narrower and researchers discuss new theories and show solutions for various problems. They now have more time to concentrate exclusively on the phenomenon.

There are many books that can be citied as examples of SCM including Inventory Management, Production Planning and Scheduling, by Edward A Silver, David F Pyke, Rein Peterson; Supply Chain Management Strategy, Planning, and Operations by Sunil Chopra and Peter Meindl; Manufacturing Planning And Control Systems For Supply Chain Management by Thomas Vollmann, William Berry, David Clay Whybark, F. Robert Jacobs. These are only some examples of recent SCM books on the market.

\subsubsection{The SCM Science Representation}

One definition of science is that it embraces a wide range of diverse disciplines and theories (Okasha, 2002) and seeks "to build and organize knowledge in the form of testable explanations and predictions about the universe" (Heilbron, 2003). Science is a contingent form of human understanding of the world. We can deduce that science builds and organizes knowledge with its explanations and predictions. Fraassen adds that the ultimate importance of science is explanation. Explanation is an application of science (Schick, 1999, p. 88).

Supply chain management science embraces the production, inventory, transportation, and other functions, relations with customers and suppliers, and the relations among the functions. SCM seeks to predict and explain why and how the phenomena among the elements of the supply chain happen. This new science claims to build and organize the knowledge and relationships that are used among the supply chain elements. SCM is in constant development, and as a paradigm, it is real. SCM is on the route to becoming a science.

Based on Figure 1, we can now represent the route of SCM to Normal Science. We saw its origin thousands of years ago, in the military campaigns of Alexander, the Roman Empire, and Genghis Khan. Those campaigns employed notions of logistics, although the term had not yet been created with a real conception of logistics. 
The term logistics was the first paradigm, created during the Napoleonic Age. With World Wars I and II the logistic term was intensified by military schools, representing many functions including procurement, maintenance, and transportation. In the 20th Century, anomalies arose, and many concepts were created which the old paradigm could not embrace. This was a time of Revolutionary Science. By the end of the 1970s, many terms were in use, such as distribution, logistics, material management, and value chains, but they were not integrated. The Council of Logistics Management generated a definition to try integrating all of the concepts, but its definition could not incorporate the relations among all of the elements of supply chain.

Around the end of the 20th century, the Supply Chain Management paradigm arose, and has developed rapidly. SCM seeks to integrate material and information within and across companies including suppliers and customers. The term logistics is now regarded as a subset of SCM, as are purchasing and production (Ballou, 2007). The route to normal science has begun; Kuhn's process to becoming a normal science is occurring.

Following Kuhn's route, SCM's definition was created to synthesize the new concept. Theories and models have been discussed in order to apply them to solve real, current problems. Many universities have programs offering certificates, BS, MBS and PhD degrees in SCM. SCM professionals are increasingly valued. Societies have been organized to discuss aspects of SCM, and many journals are achieving excellent credibility. And completing the sequence, textbooks are capturing a narrow conception and specific solutions for many applications of SCM. The route is almost complete. There now remain some refinements to be done in the alignment of SCM curricula (Ellis, 2011). Figure 3 represents the evolution just described, based on Kuhn and the state in which the authors view that SCM is today:

Figure 3 - SCM's Route to Normal Science

\section{SCM}

\section{The Route to Normal Science}

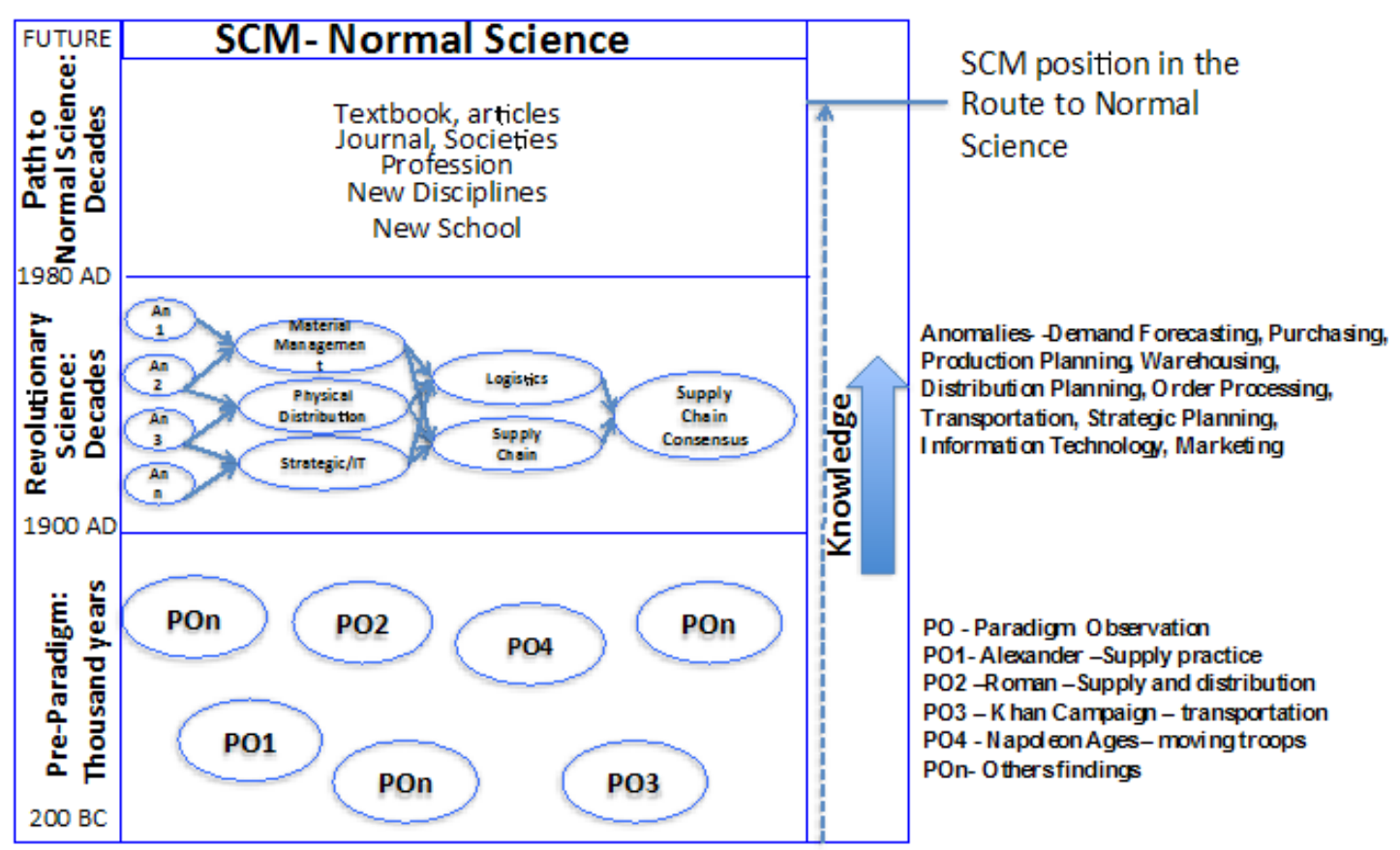




\section{CONCLUSION}

We have proposed a model of the route of SCM toward normal science by applying a Kuhnian approach. Through this approach, we can better understand an evaluative model and view SCM's progress as the evolution of a science. The Kuhnian concept aids in understanding SCM's evolution, and this model offers a comprehensive picture of its development.

This research notes that a Kuhnian analysis has been applied in numerous other studies in order to understand the evolution of their respective disciplines (Blaug, 1975; Cushing, 1989). Although some authors (Drakopoulos \& Karayiannis, 2005; Narasimhan, 1997) have criticized Kuhn's approach, his structure to explain the evolution of science can be very useful and influential (Bird, 2012; Godfrey-Smith, 2003; Okasha, 2002).

As Kuhn notes, "the road to a firm research consensus is extraordinarily arduous" (Kuhn, 1970). In the evolution of Supply Chain science, the route has indeed been arduous and consensus hasn't been easy in coming. More than two millennia have passed since humans began to apply logistical concepts. In the beginning, logistical considerations were predominantly the concern of military campaigns. Countless examples exist of the application of logistical concepts, but it took long until the knowledge came to be consolidated. As a new paradigm, SCM remains in the process of consolidation. Although acceptance of the term has grown rapidly over the last 30 years, it appears to stand further refinement. Academic should apply more energy to align SCM degree curricula and standardize point to basic curricula of SCM. Some might consider the debates between "logistics" and "SCM" to be over. For others, SCM concepts require further solidification. It may be in academia and journals where this consolidation and solidification occurs.

This paper addressed the research question of whether Supply Chain Management is a new consensus "science." This study posits that SCM is in constant development and that as a paradigm, it is real. Now SCM can be respected as a new science. This study helps to understand the maturation of SCM science and the route to normal science, and helps researchers to understand its foundation and the boundaries. Following Kuhn once more, a new paradigm can take more than two generations to gain adherents. SCM as a paradigm has been with us for about 30 years. It claims to organize knowledge regarding why and how the phenomena among the elements of the Supply Chain occur. It can be argued that it is well along the path of revolutionary science toward normal science where all definitions, disciplines are consolidated, professions and societies are assembled and textbooks are created, then the community can undertake in-depth research with specialized techniques to investigate the phenomena. The next decades will tell if SCM science completes its path becoming a normal science.

\section{REFERENCE:}

Ballou, R. H. (2007). The evolution and future of logistics and supply chain management. European Business Review, 19(4), 332-348. doi:http://dx.doi.org/10.1108/09555340710760152

Barabási, A.-L. (2003). Linked (p. 304). New York: Plume.

Bertalanffy, L. Von. (1969). General system theory: Foundations, development, applications (p. 296). New York: George Braziller Inc.; Revised edition.

Bird, A. (2012). Stanford Encyclopedia of Philosophy. "Thomas Kuhn", The Stanford encyclopedia of philosophy, E. N. Zalta (Ed.). Retrieved from http://plato.stanford.edu/entries/thomas-kuhn/

Blanchard, D. (2010). Supply chain management best practices (2nd ed.). Hoboken, NJ: John Wiley \& Sons.

Blaug, M. (1975). Kuhn versus Lakatos, or paradigms versus research programmes in the history of economics. History of Political Economy, 7(4), 399-433. doi:10.1215/00182702-7-4-399

Capra, F. (1996). The web of life: A new scientific understanding of living systems ( $1^{\circ}$ ed., p. 324). New York: Anchor Books.

Carter, C. R., Easton, P. L., Vellenga, D. B., \& Allen, B. J. (2009). Affiliation of Authors in Transportation and Logistics Academic Journals: A Reevaluation. Transportation Journal, 48(1), 42-52.

Chapman, K., \& Ellinger, A. E. (2009). Construction impact factors to measure the influence of supply chain management and logistics journals. Journal of Business Logistics, 30(2), 197-X.

CSCMP. (2004). CSCMP Council of supply chain management professionals. Retrieved December 13, 1BC, from http://cscmp.org/about-us/supply-chain-management-definitions

Cushing, B. E. (1989). A kuhnia interpretation of the historical evolution of accounting. The Accounting Historians Journal, 16(2).

Denzin, N. K., \& Lincoln, Y. S. (2005). The SAGE handbook of qualitaive research (3rd ed., p. 3). Thousand Oaks, CA: Sage Publications.

Dischinger, J., Closs, D. J., McCulloch, E., Speier, C., \& Al, E. (2006). The emerging supply chain management profession. Supply Chain Management Review, 10(1), 62-68.

Drakopoulos, S. A., \& Karayiannis, A. (2005). A Review of Kuhnian and Lakatosian "Explanations" in Economics. History of Economic Ideas, X111(16624), 51-73. 
Eckstein, A. M. (2000). The logistics of the Roman Army at war (264 BC-AD 235). The Journal of Military History, 64(1), 182-184.

Ellis, K. (2011). Exploring perceptions of consistency in university curriculum content for supply chain management. Dissertation Abstracts International Section A: Humanities and Social Sciences.

Engels, D. W. (1980). Alexander the great and the logisitics of the macedonian army (p. 157). Los Angeles, USA: University of California Press.

Ferrer, G., \& Whybark, D. C. (2001). Material planning for a remanufacturing facility. Production and Operations Management, 10(2), 112-124.

Godfrey-Smith, P. (2003). Theory and reality: An introduction to the philosophy of science (1st ed., p. 272). Chigago,IL: University Of Chicago Press. doi:10.1002/sce.20034

Goldratt, E. M., \& Cox, J. (2004). The goal: A process of ongoing improvement (3rd ed., p. 362). Great Barrington, MA: The North River Press Corporation.

Halldorsson, A., Kotzab, H., Mikkola, J. H., \& Skjøtt-Larsen, T. (2007). Complementary theories to supply chain management. Supply Chain Management, 12(4), 284-296. doi:http:// dx.doi.org/10.1108/13598540710759808

Hansson, S. O. (2012). Science and pseudo-science. (E. N. Zalta, Ed.)The Stanford Encyclopedia of Philosophy. Retrieved November 13, 1BC, from http://plato.stanford.edu/archives/ win2012/entries/pseudo-science/

Heilbron, J. L. (2003). The Oxford companion to the history of modern science. (O. U. Press, Ed.). New York, USA.

Heizer, J., \& Render, B. (2007). Principles of operations management (7th ed., p. 684). Upper Saddle River, New Jersey: Pearson/ Prentice Hall.

Hopp, W. J. (2011). Supply chain science (1st ed., p. 230). New York, NY: McGraw-Hill Irwin.

Johnson, R. B., \& Christensen, L. B. (2008). Education research: quantitative, qualitative, and mix approaches (3rd ed., p. 637). Thousand Oaks, CA: Sage Publication Ltd..

Ketchen, D. J. J., \& Hult, G. T. M. (2007). Toward greater integration of insights from organization theory and supply chain management. Journal of Operations Management, 25(2), 455.

Krafcik, J. F. (1988). Triumph of the lean production system. Sloan Management Review, 30(1), 41.

Kuhn, T. S. (1970). The structure of scientific revolutions (2nd ed., p. 210). Chicago: Chicago Press.

Lambert, D. M. (2008). Supply chain management: Process, partnerships, performance (3rd ed., p. 427). Sarasota, Fl: Supply Chain Management Institute.

Laseter, T., \& Oliver, K. (2003). When will supply chain management grow up? Strategy+business. Retrieved December 12, 1BC, from http://www.strategy-business.com/ article $/ 03304$ ?gko $=54182$

Lummus, R. R., Krumwiede, D. W., \& Vokurka, R. J. (2001). The relationship of logistics to supply chain management: devel- oping a common industry definition. Industrial Management $\mathcal{E}$ Data Systems, 101(8), 426-432. doi:10.1108/02635570110406730

Luttwak, E. (1971). Dictionary of modern war (p. 680). New York, NY: Gramercy.

Maloni, M., Carter, C. R., \& Kaufmann, L. (2012). Author affiliation in supply chain management and logistics journals: 2008-2010. International Journal of Physical Distribution \& Logistics Management, 42(1), 83-101. doi:http://dx.doi. org/10.1108/09600031211202481

Mawhinney, J. R. (2009). A determination of the essential outcomes for higher education supply chain management program success. ProQuest Dissertations and Theses. Duquesne University, United States -- Pennsylvania.

Meindl, P., \& Chopra, S. (2003). Supply chain (2nd ed.). Upper Saddle River, NJ: Prentice Hall.

Narasimhan, M. G. (1997). The Popper-Kuhn Debate on the Nature of Scientific Development In 1965, three years after the publication of Kuhn's classic,. Journal of Science Education, 2.3(1), 3.

Okasha, S. (2002). Philosophy of science. (O. U. Press, Ed.) (1st ed., p. 160). New York, USA: Oxford University Press, USA.

Oxford, U. (2012). logistics, n.2. OED Online. Oxford University Press. Retrieved from http://www.oed.com/view/Entry/1098 17 ? $r$ key $=x 2152 \mathrm{e} \&$ result $=2 \&$ isAdvanced $=$ false

Ptak, C., \& Smith, C. (2011). Orlicky's material requirements planning (3rd ed., p. 546). New York, NY: McGraw-Hill Professional.

Rossetti, C. L., \& Dooley, K. J. (2010). Job types in the supply chain management profession. Journal of Supply Chain Management, 46(3), 40-56.

Roth, J. P. (2012). The logistics of the Roman army at war (p. 399). Boston ; Köln: Brill Academic Pub.

Schick, T. J. (1999). Readings in the philosophy of science: From positivism to postmodernism (1st ed., p. 393). Mountain View-CA: Mayfield Publishing Company.

Senge, P. M. (2006). The fifth discipline: the art and practice of the learning organization (Rev. and u., p. 445). New York, USA: Doubleday.

Shaw, J. S. G. (1969). Paper 27: Supplier/Customer relationship. In Proceedings of the Institution of Mechanical Engineers, Conference (p. Vol. 184, No. 2, pp. 198-202). SAGE Publications. doi:10.1243/PIME

Silver, E. A., Pyke, D. F., \& Peterson, R. (1998). Inventory management and production planning and scheduling (3rd ed., p. 784). Hoboken-Nj: John Wiley \& Sons.

Simchi-Levi, D., Kaminsky, P., \& Simchi-Levi, E. (2007). Design and managing the supply chain: Concepts, strategies and case studies (3rd ed., p. 498). New York, NY: McGraw-Hill Irwin.

Weatherford, J. (2004). Genghis Khan and the making of the modern world (p. 309). New York, USA: Three Rivers Press.

Zikmund, W. G., \& Stanton, W. J. (1971). Recycling Solid Wastes: A Channels-of-distribution Problem. Journal of Marketing, 35(3), 34-39. 


\section{Appendices A - Societies and Journals}

\section{Examples of SCM Societies}

\begin{tabular}{|c|c|}
\hline Society & Site \\
\hline Council of Supply Chain Management Professional & http://cscmp.org \\
\hline The Institute for Supply Management ${ }^{\mathrm{TM}}$ (ISM) & http://www.ism.ws \\
\hline Institute for Operations Research and the Management Sciences (INFORMS) & http://www.informs.org \\
\hline Production and Operations Management Society & http://www.poms.org \\
\hline Association for Supply Chain and Operations Management (APICS) & http://www.apics.org \\
\hline European Operations Management Association (EurOMA) & http://www.euroma-online.org \\
\hline Decision Sciences Institute (DSI) & http://www.decisionsciences.org \\
\hline SCM World & http://www.scmworld.com \\
\hline
\end{tabular}

\section{Examples of Journals of Logistics, Operations Management, Supply Chain Management, Transportation}

\begin{tabular}{|l|l|}
\hline \multicolumn{2}{|c|}{ Journal } \\
\hline Computers and Operations Research & Management Science \\
\hline Decision Science & Omega- The International Journal of Management Science \\
\hline European Journal of Operations Research & Operations Research Letter \\
\hline Interfaces & Production and Operations Management: \\
\hline International Journal of Logistics Management & Supply Chain Management: An International Journal \\
\hline International Journal of Logistics: Research and Applications & Transport Policy: \\
\hline International Journal of Operations and Production Management & Transportation Research Part A \\
\hline International Journal of Physical Distribution and Logistics Management & Transportation Research Part B \\
\hline International Journal of Production Economics & Transportation Research Part C: \\
\hline Journal of Business Logistics International & Transportation Research Part D \\
\hline Journal of Operations Management & Transportation Research Part E \\
\hline Journal of Operations and Supply Chain Management & Transportation Research Part F \\
\hline Journal of Production Research & Transportation Research Record: \\
\hline Journal of Purchasing and Supply Management & Transportation Science \\
\hline Journal of Supply Chain Management & Transportation \\
\hline
\end{tabular}




\section{AUTHOR'S BIOGRAPHY:}

Rogers Ascef received a master degree in administration from IBMEC in Rio de Janeiro in 2005 and he has certificates in System Analysis from the Air Force Technology Institute (ITA-1996), in Production Engineering from the University Federal of Rio de Janeiro-1999, and in Supply Chain Management from Lehigh University-2009. He is finishing his PhD at Naval Postgraduate School in December 2014.

Geraldo Ferrer is an Associate Professor. His areas of expertise include supply chain management, product stewardship, and remanufacturing. He has published on these topics in numerous journals, presented his research in national and international conferences, and in various invited seminars. He received his PhD INSEAD (France), MBA - Dartmouth College, and BS Mechanical Engineering -IME-RJ

Steven Mullins holds an MBA from Golden Gate University. He is a doctoral student in Information Sciences at the U.S. Naval Postgraduate School in Monterey, CA, USA. 